\title{
Andy Kesson. John Lyly and Early Modern Authorship. Manchester: Manchester University Press, 2014. Pp 241.
}

TARA L. LYONS

Early Theatre 18.1 (2015), 136-9

Illinois State University

DOI: http://dx.doi.org/10.12745/et.18.1.2556

In John Lyly and Early Modern Authorship, Andy Kesson sets out to restore Lyly to the heights of literary respectability that he enjoyed in early modern England. Kesson's Lyly is not the sycophantic or effeminate writer of frivolous romances, as scholars have often maintained, but a groundbreaking prose fiction author, a revolutionary dramatist, and the 'most famous Elizabethan writer in his own time' (3). To help scholars see Lyly as many of his contemporaries did, Kesson examines the writer's prose and dramatic works, their literary and bibliographical innovations, and their impact on other writers and the English book market. The volume consists of three parts: the first addresses Lyly's prose fiction, the second examines his drama, and the third explores the historical processes by which Lyly was relegated to the margins of the English Renaissance canon. The book's fresh focus on Lyly's print reception and authorial construction from the sixteenth century onward makes it a valuable contribution to Renaissance scholarship.

For Kesson, the blight on Lyly's authorship in past and current criticism has no basis in the early modern period. Instead, it is a product of eighteenth- and nineteenth-century literary discourses and their obsession with Shakespeare's exemplarity. For the Bard of Avon to emerge as the epitome of Renaissance authorship, Lyly's contributions to English culture had to be diminished. As Kesson poignantly states, 'In the eighteenth century Lyly is repeatedly described as an infection or disease for which Shakespeare was the cure' (5). It seems that Lyly's reputation never recovered, but nursing it back to health is Kesson's primary agenda in this book.

Chapters 1 and 2 show how Lyly's Euphues publications created the market for single-story books in prose and transformed the marketing and narrative structures of English prose fiction in the sixteenth century and beyond. Chapter 1 concerns itself with Lyly's first highly successful publication, Euphues: The Anatomy of Wit (1578). While scholars typically treat the rhetorical flourishes of euphuism as the book's most influential feature, Kesson argues that the volume had lasting effects on the market for prose fiction. Unlike George Painter's Palace of Pleasure (1566), which compiled a series of prose stories in one volume, or George Gascoigne's The Adventures 
of F.J. (1573), which was issued in a collection of the author's works, Lyly's The Anatomy of Wit offered a singular, unified storybook that focused on a central character. The impact of Lyly's and his publisher's decisions on the emerging fiction market were far-reaching, and Kesson's evidence for this claim is the substance of chapter 2. Here, he illuminates the ways that Lyly's readers after 1578 adapted his narrative model for single-story fiction and appropriated 'Euphues' as a marketing device for their own publications. In so doing, this chapter offers a necessary corrective to G.K Hunter and others who have perpetuated the notion that Lyly's literary influence declined after the 1580s.

Chapters 3 and 4 argue for Lyly's importance to the development of early modern drama in performance and in print. Through careful close readings of Lyly's plays as well as their prologues and epilogues, Kesson persuasively shows how he constructed his audiences as participants in his drama. For Lyly, the meaning of a performance was the 'imaginative responsibility' of each audience (111). This semiotic instability, which Kesson claims was new to English drama, also manifests in Lyly's construction of dramatic characters who, like Euphues, were protean and elusive. When actors performed these roles, audiences saw physical bodies transformed on stage and characters' significations altered across a play or a series of plays, such as that of Cupid across Sapho and Phao, Gallathea, and Love's Metamorphosis. In chapter 3 Kesson concentrates solely on Lyly's innovations within his own works rather than on his wider influence, yet this offers a productive model for interpreting the shifting identities that early modern characters in both prose and drama so often inhabit.

Chapter 4 then sets out to illustrate how Lyly's drama was vital to the formation of the market for printed plays from the professional theatres. Here, Kesson engages in debates about when and how the market for printed plays emerged in England. Current scholarship identifies 1594 as a watershed year for playbook publication and, in their work on the popularity of playbooks, Alan Farmer and Zachary Lesser cite this 1594 'boomlet' as an unusual, brief expansion in a playbook market that did not pick up speed until after $1598 .{ }^{1}$ Kesson wants to backdate the emergence of the market to 1584 and 1591-2 when Lyly's ten playbooks were published. It was Lyly's drama, he argues, that legitimated the publication of professional drama and encouraged the growth of the playbook market in and after 1594 .

This is Kesson's least persuasive chapter, and his misreading of sources and evidence to favor Lyly's prominence exposes a fault line in the book as a whole. 
To position Lyly's drama as seminal to the playbook market in the late sixteenth century, Kesson contends that scholars have excluded Lyly's plays in their data on professional drama. He targets Farmer and Lesser's research on the popularity of playbooks, inferring that they left out Lyly's plays from their calculations on 'professional' drama because of the plays' provenance in the indoor theatres $(144,147)$. With Lyly's ten editions factored into this data, Kesson proposes, the 'boomlet' of 1594 looks much less impressive. Kesson's reasoning here is sound, but his facts are wrong. In 'Popularity', Lyly's plays are factored into the data on professional playbook publication. ${ }^{2}$ Farmer and Lesser don't exclude Lyly; they simply don't see a causal relationship between the publication of Lyly's 10 editions (5 published in 1584 and 5 in 1591-2) and the expansion of the playbook market, which they argue occurred not in 1594, as Kesson mistakenly infers (142), but from 1598 to 1613 when 'publishers brought out almost five times as many plays per year as they had done earlier.' ${ }^{3}$ How Kesson came to his conclusions about Lyly's omission from these scholars' data is unclear, but similar mistakes appear elsewhere. In one instance, Kesson again cites the omission of Lyly's drama from Farmer and Lesser's statistics on new plays first printed and then reprinted between 1589 and 1597 (151). Kesson wants to include Campaspe, Sapho and Phao, and Mother Bombie in this data, but none of these plays fit the criteria. Campaspe and Sapho and Phao had been in print since 1584, and Mother Bombie was first printed in 1594 but not reprinted before 1598. Factual errors like this do not compromise Kesson's more tenable claim that Lyly's drama may have helped jumpstart the playbook market, but they are symptomatic of larger problems in the monograph: Kesson is so devoted to the recuperation of Lyly's reputation that he sees the author missing from scholarship when he is not.

The book also tends to exaggerate the influence of Lyly's authorship where there is little evidence of its import. For example, when considering why Lyly's name was left off the title pages of his playbooks in 1591-2, Kesson proposes that the authorship of the plays was so well established that the publishers didn't even need to use Lyly's name. A more plausible conclusion is that Lyly's publishers were invested in other features of the playbooks: the playing companies and performance before Queen Elizabeth, for instance both features that were advertised on the title pages. Indeed, the publisher of Endymion (1591), Joan Broome, makes efforts to highlight the performance venue and court performance in her note to the reader, but makes no mention of Lyly. To interpret his absence as a sign of his prominence in the period is 'contentious' (150), as Kesson admits, but it also exposes a willingness to 
overlook material evidence to tout Lyly's purported fame. A more productive discussion could tell us why Lyly's popularity as a prose writer did not carry over into the marketing of his drama or why the success of Lyly's prose fiction failed to boost the sales of his printed plays in the 1590s. Only one of the seven playbooks printed in the 1590s merited another edition before 1632, and yet Kesson clings to the claim that the plays were 'selling well' and demonstrate the author's widespread cultural relevance (126).

Nevertheless, Kesson's fifth chapter is a compelling reminder of just how long Lyly's authorship has been the victim of misguided and unsupported critical appraisals. In this short history of the word 'euphuism', Kesson reveals that the term had no stable meaning for Lyly's contemporaries, but throughout the eighteenth and nineteenth centuries came to describe writing that was artificial, pretentious, diseased, and effeminate - the opposite of Shakespeare's natural, masculine, and salutary lines. These negative associations with 'euphuism' became detrimental to Lyly's reception, as critics conflated the author with the corruption and inappropriate excess that the word connoted. Kesson persuasively argues that much of the bias against Lyly and his authorship today derives from this critical treatment.

John Lyly and Early Modern Authorship is published in the Revels Plays Companion Library, a series devoted to publishing criticism that explores 'the achievements of the major dramatists' of the English Renaissance. Although Kesson's claims about Lyly's preeminence are often overstated, this book does much to reestablish the terms on which Lyly can be considered not only a 'major dramatist' but also a major author of his time.

\section{Notes}

1 Alan B. Farmer and Zachary Lesser, 'The Popularity of Playbooks Revisited', Shakespeare Quarterly 56.1 (2005), 9-10, doi: http://dx.doi.org/10.1353/shq.2005.0043

2 On p. 7 of 'Popularity', Farmer and Lesser report that forty-eight first editions and eleven second-plus editions of professional plays were published from 1576 to 1589 . The Database of Early English Playbooks (http://deep.sas.upenn.edu) confirms the accuracy of these numbers and that Lyly's titles are included in this data. These results can be replicated by searching the database for 'Single-Play Playbooks' and 'Collections' and then limiting the search to 'Professional' and 'First' editions or 'Second-plus' editions.

3 Farmer and Lesser, 10. 